\title{
Regional Disparities in Socio Economic Development in Thar Desert
}

\author{
Dr. Pawan Kumar Sharma \\ Assistant Professor, Department of General \& Applied Geography \\ Dr. Hari Singh Gour University (A Central University) \\ Sagar-470003 (M.P.) India
}

\begin{abstract}
The idea of analysis of regional disparities in the socio-economic development is relevant for integrated area development because we cannot provide all services and development programmes for all settlement due to scarcity of resources. Hence, it is essential to identify the most suitable location for allocation of important services. There are widespread disparities in the levels of social and economic development between the regions and also within the region. Regional disparities in development in India have remained static in spite of overall development efforts made during the plan periods. Regional disparities in relation to poverty income and unemployment have been increasing among the different regions of a state (vertical) and in the districts within the regions of the state (horizontal). Rajasthan is also characterized by economic imbalance. All the relative indicators indicate that the Eastern Plain Region occupies a balanced status followed by the Aravali Hills and Plateau regions. So far as the Western Desert Region is concerned it was at a disadvantageous position in terms of status of relative development. The economy of the study area being agrarian, Net Domestic Product is largely dependent on agriculture production, which is subjected to wide flections, depending on the monsoon conditions. There is a need of a suitable development strategy, an area specific planning approach based on proper and efficient use of resources and potentials to secure regional balance and final solutions to the problems of the economy of Western Rajasthan. There is no reason to believe that if so desired why desert state cannot touch the heights of development and make a place for itself in the galaxy of other developed states of this country? The raw data (Based on Census, 2011) have been converted into ratio or percentage according to the requirement of the analysis. The indicators used in the present paper have been divided in 4 groups i.e. demographic, agricultural, infrastructural and economic. By using composite index method development in each aspects have been find out among the 12 Desert Districts of Western Rajasthan.
\end{abstract}

Keywords: Regional disparities, Thar Desert, Composite index method, Level of Development

\section{INTRODUCTION}

Rajasthan is a largest state of the nation and it is well known for the widespread disparities in the levels of social and economic development between the different micro regions. Balanced regional development has always been an essential component of the state development strategy in order to ensure the minimum living standard of the rural people of the state. The concept of regional disparity has been quintessential in all geographical thinking. Such variation in terms of resource management and overall socio-economic progress reflect the levels of development in a state like Rajasthan. On one hand there are large urban centers which are growing in size and are centres of materialistic culture and on other, there are vast rural areas where about eighty per cent of her people still remain backward and are devoid of even basic amenities like water supply, sanitation, education etc. Spatial imbalance has got accounted with the economic progress in the Great Indian Desert. We do not mean imaginary equalization of all regions when we talk of balanced regional development. Such equalization is in fact not possible. Various factors are responsible for spatial variation in level of development like physical landscape, economic growth, political pressure, involvement of local people, skilled labour, irrigated land, industrial capital credit, infrastructural etc. The main objective 


\section{Dr. Pawan Kumar Sharma}

of the present study is to identify regional disparities in development in the Thar Desert in western Rajasthan.

Raghuram Rajan Committee for Evolving a Composite Development Index of States Using MultiDimensional Index categorized Rajasthan as Least Developed state. The Western Rajasthan is at extreme backwardness, which is largely the result of peculiar physical feature of the area, a traditional society and a static economy in the years preceding. The state itself has remained much below the economic level attained in the rest of country. Against this backdrop, there is a need to identify the regions or areas which are backward, to find out the extent and nature of backwardness and to look into the dynamics of the regional backwardness over space and time. The present study is an attempt in this direction.

An attempt is made to trace the social-economic structure in Western Rajasthan. Keeping the volatility of social infrastructure and amenities for the promotion of development in view, to study the existing infrastructure and social amenities of the area under study with the set objective to assess their impact on the exploitation of its physical and human resources. This in-depth analysis raises three basic questions, namely, why is there an enormous gap between differentially developed districts? Why is such a gap increasing? And why is development concentrated only in a few centers/areas? Answers to these questions are sought with the help of an analysis of dimensions of development and typology of backwardness. It is sought that this will highlight the major findings of the present study and also give valuable policy suggestions to all those who are interested in the development process of Western Rajasthan.

\section{The STUdy AREA}

The Population of Rajasthan according to the 2011 census stands at about 68 million, making it the 8th most populated state in India. The state makes up about $5.6 \%$ of the country's population. The state is spread over an area of about $\mathbf{3 4 2 , 2 3 9}$ sq. $\mathrm{km}$. making it the largest state in the country in terms of area. The Aravalli hill ranges, running from north- east to south-west, divides the state into the western arid and eastern semi-arid region. Rajasthan has been divided into four Physiographic regions, i.e.,( Singh,R.L.1971)

Physiographic divisions of Rajasthan

- The Western Sandy plain

- The Aravalli Range \& Hilly Region

- The Eastern Plain

- The south-Eastern Plateau

The study area 'Western Rajasthan' is situated in the western part of Rajasthan. (Fig.1). This region includes 12 western districts of Rajasthan, which covers an area of 208,746 sq. kms with a population of $27,115,542$ persons as per census 2011 . The study area makes up about 60.99 percent area and 39.51 percent population of the state.

Table1. Physiographic divisions of the Study Area

\begin{tabular}{|c|c|c|c|}
\hline Region & Division & Sub-Division & Districts(12) \\
\hline \multirow{6}{*}{$\begin{array}{l}\text { Western } \\
\text { Rajasthan } \\
\text { (Western } \\
\text { Sandy } \\
\text { Plain) }\end{array}$} & \multirow[t]{2}{*}{ Sandy Arid Plain } & Marusthali & \multirow{6}{*}{$\begin{array}{l}\text { Hanumangarh, Sriganganagar, } \\
\text { Bikaner, Jaisalmer, Barmer, Jalore, } \\
\text { Pali, Jodhpur, Nagaur, Churu, Sikar } \\
\text { \& Jhunjhunu }\end{array}$} \\
\hline & & Dune Free Tract & \\
\hline & \multirow{4}{*}{$\begin{array}{l}\text { Semi-Arid Plain } \\
\text { (Bangur Region) }\end{array}$} & Ghaggar Plain & \\
\hline & & Shekhawati & \\
\hline & & Naguri upland & \\
\hline & & Luni Basin & \\
\hline
\end{tabular}



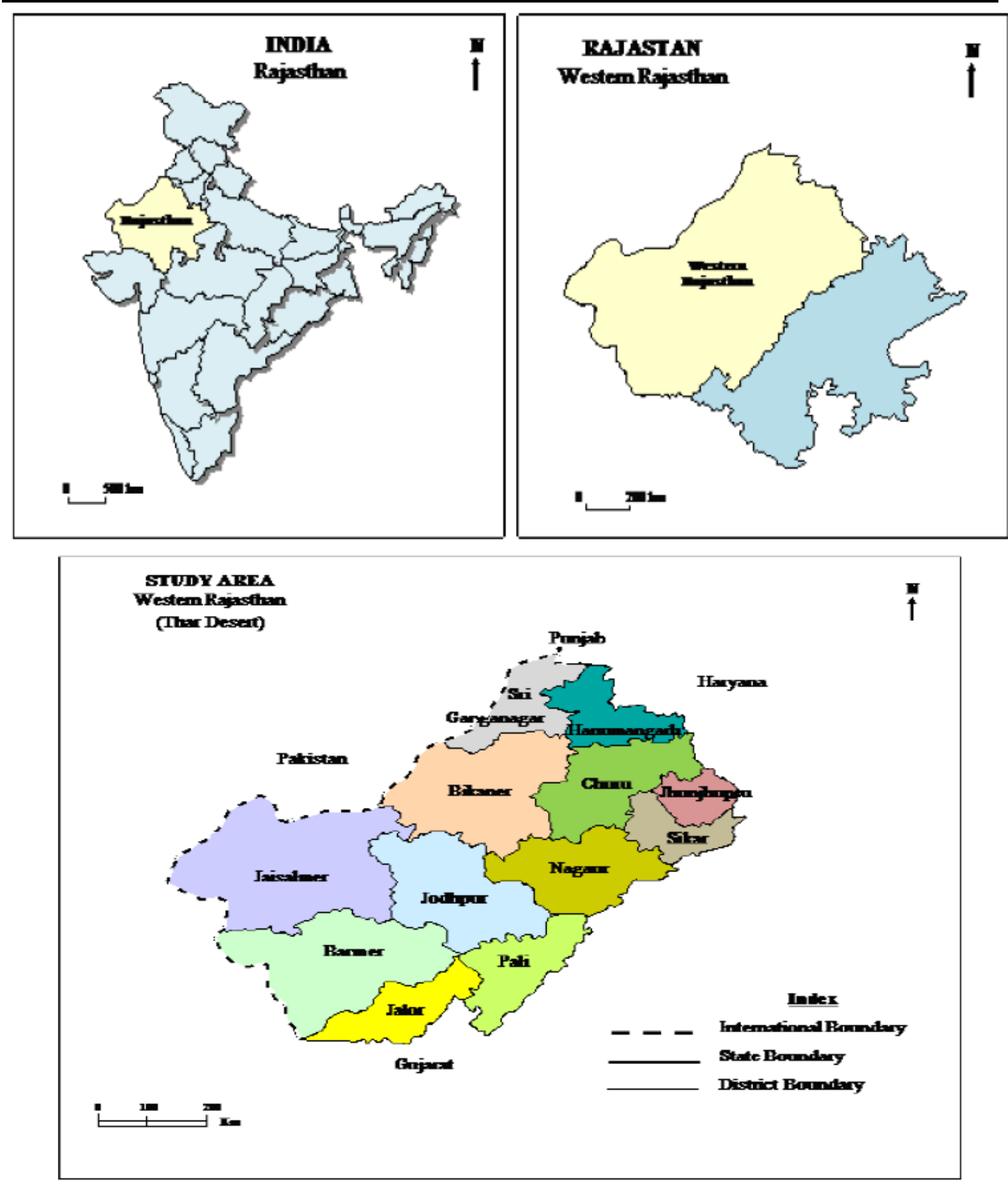

Fig1. Location Map

The area is characterized by arid landscape with various types of sand dunes. It is dry and ill watered, unkind to all form of life, animal and plant. The study area has a desert climate characterized by extreme temperature and erratic rainfall. This area is lacking in water, biotic resources and infrastructure facilities with poor human development index. Due to scattered settlement and more spacing among them, it is difficult to provide all infrastructural facilities at village level because of lack of population threshold.

The Thar desert region of Western Rajasthan is at extreme backwardness, which is largely the result of peculiar physical feature of the area, a traditional society and a static economy in the years preceding. Most of the villages of the Study area do not have even the basic necessities like Drinking water, Education, Health, Transportation and other services. The study area has remained much below the economic level attained in the rest of state. There is no proper spatial distribution of services at the Micro - level due to scattered and more spacing among the settlement. 


\section{OBJECTIVES}

The present study is intends to fulfil the following objectives:

1. To analyses the factors responsible for the inequalities in socio-economic development among the Thar Desert.

2. To assess the natural and human resources and classify the districts into Backward region, least developed, less developed and relatively developed.

3. To make identification of the relatively backward areas within the study area and identify existing gaps and assess future demand for socio- economic infrastructure and prepare rational planning.

\section{Database ANd Methodology}

The present study is mainly based on secondary data obtained from census of India (2011) and statistical handbook of Rajasthan. Other relative data collected from various official sources such as publications of the Directorate of Economics and Statistics, the Revenue Board of Rajasthan, Departments of Agriculture, Department of Industry and Department of Environment and Forest. This research aims to measure the spatial variation in the level of development in Western Rajasthan at district level, with the help of multi-variable data analyzing methods based on a determined system of viewpoints. The presented model and the methodology based on it are suitable for making spatial variation measurable. Through this and with the help of statistical data, the spatial variation of any territorial unit of any level can be determined.

A number of methods have been used to study the spatial variation. Main work in this direction was done by Mitra, A. (1961). He used 35 indicators to highlight regional disparities through ranking method. The same method has been also used by Mahesh Chand and Puri, V.K. (1983). Roa \& Puri (1971), Dasgupta (1971) and Pal, M. N. (1975) have used multiple factor analysis and the method of principal component analysis to study spatial variation in level of development. The method has been widely used by Sharma, K.L. (1975) Mandal, S.K. (1971) Hagood, M.S. (1977) and Mishra, R.P. (1978).

The Principal Component Method of factor analysis was developed by H. Horelling (1933). The weights used in this case are the elements of the Eigen vector corresponding to the highest Eigen vector of the correlation matrix $(\mathrm{R})$ are of the selected variables. Eigen vector has been used here as it gives relative importance to each variable, which is very important for the identification of level of development.

Primary work in this direction was done by Smailes (1944), Dickinson (1964), Berry (1968), Garison (1968) and Guttman (1969). An important work in this direction was done by Kim. (1999), Jeffrey (1965), Freeman C.(1987), Grossman G. and Helpman E., (1991), Lundvall B. (1992), Nelson R., (1993), Anthony J. (2005), Elbers, and Kenneth R. (2005), Venables. J. (2005), Pike A., RodríguezPose A. and Tomaney J. (2006) etc.

In India the evolution of spatial variation in the level of development has been investigated by number of authors viz.. Agarwala, A.K. and Hazarika, P.L. (2002), Ahluwalia, Montek S. (2000), Arora, R.C. (1979),Debapriya, A. and Mohanty, M.K. (2006), Nagaraj, R, Aristomene Varoudakis and Marie-Ange Veganzones (1998), Nair K.R.G. (2004), Naseer, Y., Siddiqui, F.A. and Kazma Khan (2005), Rao, Hemlata, (1984), Shand, Ric and S. Bhide (2000), Singh R. (2006), L.K. Sen(1994), L.S. Bhatt, (1972), R.L. Singh(1971), .Pal(1975), R.P. Mishra (1978) etc. They have done pioneer work in the field of regional development, identified backward areas and suggested various impressive strategies for the balanced development of the region.

Present research aims to measure the spatial variation in the level of development in Western Rajasthan at district level, with the help of multi-variable data analyzing methods based on a determined system of viewpoints. The presented model and the methodology based on it are suitable for making spatial variation measurable. Through this and with the help of statistical data, the spatial variation of any territorial unit of any level can be determined.

In order to make the study comprehensive and more analytical both empirical and statistical methodologies have been adopted for the different aspects of the study. The indicators, which are used in the present study, have been divided into four groups, that is 
- Demographic Indicators

- Economic Indicators

- Socio-Cultural Indicators

- Infrastructural Indicators

The identification of regional growth patterns is an important factor affecting policy formulation. Single indicator, usually GDP-based, approaches have revealed significant shortcomings. In present work, I have provided a new methodology and respective tools to analyze regional disparities and development patterns. Aiming at capturing the different aspects of development and quality of life my approach is multi-dimensional: I have, first, developed a composite index; then, apply multivariate clustering for identifying regions with similar socio-economic profiles.

An attempt has been made in the measures of different level of development to construct a composite index by combining and grouping different indicators into four sectors, so that the composite indicator could be used to differentiate spatial units like districts for level of economic development. The study summarizes 24 indices identified for each of the four sectors which reflect the development characteristics (Table 2)

Table 2. Development Indicators

\begin{tabular}{|l|l|l|l|l|l|l|l|}
\hline $\begin{array}{l}\text { S. } \\
\text { No. }\end{array}$ & District & $\begin{array}{l}\text { Population } \\
\text { Growth } \\
(2001-2011)\end{array}$ & $\begin{array}{l}\text { \% of net } \\
\text { irrigated } \\
\text { area of net } \\
\text { cropped area }\end{array}$ & $\begin{array}{l}\text { \% of main } \\
\text { workers to } \\
\text { total workers } \\
2011\end{array}$ & $\begin{array}{l}\text { \% of villagers } \\
\text { having electric } \\
\text { facility }\end{array}$ & $\begin{array}{l}\text { \% of } \\
\text { Urban } \\
\text { population } \\
(2011)\end{array}$ & $\begin{array}{l}\text { No. of } \\
\text { Livestock } \\
\text { per 10000 } \\
\text { population }\end{array}$ \\
\hline 1 & Barmer & 32.55 & 9.19 & 61.7 & 96.10 & 7.0 & 21179 \\
\hline 2 & Bikaner & 24.48 & 16.64 & 76.3 & 98.71 & 33.9 & 15182 \\
\hline 3 & Churu & 20.35 & 7.27 & 69.6 & 100 & 28.3 & 11099 \\
\hline 4 & Ganganagar & 10.06 & 75.48 & 74.6 & 95.62 & 27.2 & 8016 \\
\hline 5 & Hanumangarh & 17.24 & 44.54 & 76.9 & 97.3 & 19.7 & 8214 \\
\hline 6 & Jaisalmer & 32.22 & 1396 & 60.7 & 78.21 & 13.3 & 48616 \\
\hline 7 & Jalore & 26.31 & 41.09 & 73.7 & 99.12 & 8.3 & 12542 \\
\hline 8 & Jhunjhunu & 11.81 & 52.69 & 66.3 & 100 & 22.9 & 6524 \\
\hline 9 & Jodhpur & 27.69 & 19.37 & 70.9 & 100 & 34.3 & 1362 \\
\hline 10 & Nagaur & 19.25 & 18.51 & 69.1 & 100 & 19.3 & 11694 \\
\hline 11 & Pali & 11.99 & 18.45 & 71.9 & 100 & 22.6 & 15203 \\
\hline 12 & Sikar & 17.04 & 45.10 & 69.4 & 100 & 23.7 & 7856 \\
\hline & X & 20.91 & 30.19 & 70.09 & 97.8 & 21.70 & 13957.25 \\
\hline & S.D. $(\sigma)$ & 4.57 & 5.49 & 6.28 & 5.44 & 11.51 & 8732.77 \\
\hline
\end{tabular}

Development Indicators

\begin{tabular}{|l|l|l|l|l|l|l|l|}
\hline $\begin{array}{l}\text { S. } \\
\text { No. }\end{array}$ & $\begin{array}{l}\text { District } \\
\text { Registered } \\
\text { Vehicles/ } \\
10000 \\
\text { population }\end{array}$ & $\begin{array}{l}\text { Length } \\
\text { of roads/ } \\
10000 \\
\text { Sq.Km. } \\
(2011)\end{array}$ & $\begin{array}{l}\text { Literacy } \\
\text { Rate } \\
(2011)\end{array}$ & $\begin{array}{l}\text { Number of } \\
\text { beds in hospital } \\
\& \text { dispensary/ } \\
10000 \\
\text { population } \\
(2011)\end{array}$ & $\begin{array}{l}\text { Agricultural } \\
\text { output } \\
\text { (Ton)/ } \\
10000 \\
\text { Population } \\
(2011)\end{array}$ & $\begin{array}{l}\text { \% of non- } \\
\text { agriculture } \\
\text { workers/total } \\
\text { workers } \\
(2011)\end{array}$ \\
\hline 1 & Barmer & 380.70 & 1713.20 & 56.50 & 4 & 280.20 & 86.1 \\
\hline 2 & Bikaner & 1240.18 & 1502.32 & 65.1 & 18 & 274.40 & 86.2 \\
\hline 3 & Churu & 317.68 & 1755.18 & 66.8 & 8 & 351.70 & 89.1 \\
\hline 4 & Ganganagar & 1741.32 & 1138.72 & 69.6 & 7 & 490.60 & 59.3 \\
\hline 5 & Hanumangarh & 792.17 & 1540.80 & 67.1 & 5 & 697.10 & 78.1 \\
\hline 6 & Jaisalmer & 298.75 & 826.73 & 57.2 & 6 & 227.7 & 78.8 \\
\hline 7 & Jalore & 470.24 & 2877.15 & 54.9 & 3 & 284.9 & 77.1 \\
\hline 8 & Jhunjhunu & 683.35 & 4354.12 & 74.1 & 9 & 384.60 & 92.2 \\
\hline 9 & Jodhpur & 1456.16 & 2647.30 & 65.9 & 17 & 315.20 & 92.2 \\
\hline 10 & Nagaur & 774.46 & 3183.62 & 62.8 & 5 & 360.20 & 75.4 \\
\hline 11 & Pali & 823.60 & 3618.38 & 62.4 & 8 & 241.70 & 54.9 \\
\hline 12 & Sikar & 647.92 & 3629.91 & 71.9 & 12 & 417.90 & 89.3 \\
\hline & X & 802.21 & 2405.62 & 64.53 & 8.5 & 360.51 & 78.39 \\
\hline & S.D. $(\sigma)$ & 435.30 & 1037.67 & 12.16 & 5.1 & 147.60 & 7.93 \\
\hline
\end{tabular}




\section{Dr. Pawan Kumar Sharma}

Development Indicators

\begin{tabular}{|l|l|l|l|l|l|l|l|}
\hline $\begin{array}{l}\text { S. } \\
\text { No. }\end{array}$ & District & $\begin{array}{l}\text { Number of } \\
\text { Banks/Lakh } \\
\text { population } \\
(2011)\end{array}$ & $\begin{array}{l}\text { Deposits } \\
\text { of banks } \\
\text { per person } \\
(2011)\end{array}$ & $\begin{array}{l}\text { Credit of } \\
\text { banks per } \\
\text { person } \\
(2011)\end{array}$ & $\begin{array}{l}\text { No. of } \\
\text { Primary } \\
\text { schools to } \\
10000 \\
\text { population }\end{array}$ & $\begin{array}{l}\text { \% of school } \\
\text { going } \\
\text { children to } \\
\text { total children }\end{array}$ & $\begin{array}{l}\text { \% of double } \\
\text { cropped area } \\
\text { to total } \\
\text { cultivated } \\
\text { area (2011) }\end{array}$ \\
\hline 1 & Barmer & 6 & 2643 & 1018 & 18.11 & 80.01 & 6.42 \\
\hline 2 & Bikaner & 12 & 8336 & 3278 & 9.17 & 79.30 & 23.52 \\
\hline 3 & Churu & 9 & 4985 & 1632 & 6.86 & 82.42 & 4.72 \\
\hline 4 & Ganganagar & 12 & 7761 & 4562 & 10.84 & 85.33 & 43.42 \\
\hline 5 & Hanumangarh & 9 & 4389 & 2913 & 7.55 & 80.26 & 40.76 \\
\hline 6 & Jaisalmer & 10 & 3910 & 1492 & 20.71 & 78.12 & 7.15 \\
\hline 7 & Jalore & 6 & 2878 & 940 & 11.43 & 87.40 & 32.63 \\
\hline 8 & Jhunjhunu & 7 & 6283 & 1469 & 9.64 & 97.40 & 9.67 \\
\hline 9 & Jodhpur & 8 & 8481 & 3645 & 11.17 & 89.42 & 6.12 \\
\hline 10 & Nagaur & 7 & 3734 & 946 & 10.45 & 87.88 & 14.75 \\
\hline 11 & Pali & 8 & 53.18 & 1320 & 9.69 & 86.73 & 21.14 \\
\hline 12 & Sikar & 9 & 6271 & 1530 & 9.96 & 91.32 & 11.38 \\
\hline & X & 8.58 & 5415.75 & 2062.08 & 11.29 & 85.52 & 18.47 \\
\hline & S.D. $(\sigma)$ & 1.72 & 3140.7 & 1855.88 & 3.63 & 6.84 & 9.35 \\
\hline
\end{tabular}

Development Indicators

\begin{tabular}{|l|l|l|l|l|l|l|l|}
\hline S.No. & District & $\begin{array}{l}\text { \% of } \\
\text { college } \\
\text { students } \\
\text { to total } \\
\text { student }\end{array}$ & $\begin{array}{l}\text { Number of } \\
\text { Education } \\
\text { centres/Sq.km. } \\
(2011)\end{array}$ & $\begin{array}{l}\text { Land Revenue } \\
\text { per head of } \\
\text { population } \\
(2011)\end{array}$ & $\begin{array}{l}\text { Postal } \\
\text { Services } \\
\text { per 100 } \\
\text { sq.km. }\end{array}$ & $\begin{array}{l}\text { Cooperative } \\
\text { societies/1000 } \\
\text { population } \\
(2011)\end{array}$ & $\begin{array}{l}\text { Total milk } \\
\text { production in } \\
\text { Kgs./1000 } \\
\text { population } \\
(2011)\end{array}$ \\
\hline 1 & Barmer & 8.62 & 0.05 & 4.86 & 2 & 0.32 & 129 \\
\hline 2 & Bikaner & 17.29 & 0.09 & 2.78 & 1 & 0.67 & 226 \\
\hline 3 & Churu & 14.72 & 0.19 & 2.86 & 3 & 0.41 & 120 \\
\hline 4 & Ganganagar & 19.32 & 0.17 & 5.85 & 2 & 0.64 & 218 \\
\hline 5 & Hanumangarh & 16.75 & 0.23 & 7.05 & 3 & 0.33 & 226 \\
\hline 6 & Jaisalmer & 11.46 & 0.04 & 31.94 & 1 & 0.52 & 203 \\
\hline 7 & Jalore & 13.59 & 0.18 & 7.85 & 3 & 0.39 & 175 \\
\hline 8 & Jhunjhunu & 21.42 & 0.53 & 4.81 & 9 & 0.23 & 180 \\
\hline 9 & Jodhpur & 8.74 & 0.21 & 7.10 & 2 & 0.50 & 192 \\
\hline 10 & Nagaur & 13.15 & 0.24 & 5.25 & 4 & 0.24 & 113 \\
\hline 11 & Pali & 14.72 & 0.20 & 11.35 & 4 & 0.45 & 154 \\
\hline 12 & Sikar & 19.10 & 0.47 & 6.16 & 8 & 0.20 & 129 \\
\hline & X & 14.56 & 0.21 & 8.16 & 3.8 & 0.41 & 160.42 \\
\hline & S.D. $(\sigma)$ & 3.16 & 0.13 & 6.12 & 1.7 & 0.13 & 58.37 \\
\hline
\end{tabular}

These 24 indices are firstly subtracted from their mean and then divided by their standard deviation separately for each district and thus we get standardized values for each district. These values of indices are grouped under each of the 4 sectors and are worked together under each sector to aggregate them into one. The sum of standardized values of each sector is then divided by the number of variables that have been chosen into each sector and composite index has been worked out (Table 3).

Table 3. Value of composite index for various development sectors

\begin{tabular}{|l|l|l|l|l|l|}
\hline S. No. & Districts & Demographic sector & Agriculture Sector & Economic Sector & Infrastructural Sector \\
\hline 1 & Barmer & 0.17 & -0.67 & -0.43 & -0.19 \\
\hline 2 & Bikaner & 1.05 & -0.69 & 0.52 & 0.16 \\
\hline 3 & Churu & 0.42 & -0.39 & -0.36 & -0.65 \\
\hline 4 & Ganganagar & 0.48 & 1.32 & -0.18 & -0.41 \\
\hline 5 & Hanumangarh & 0.13 & 1.32 & -0.03 & -0.58 \\
\hline 6 & Jaisalmer & 0.60 & -1.53 & 1.24 & -0.31 \\
\hline 7 & Jalore & -1.05 & -0.81 & -0.48 & -0.04 \\
\hline 8 & Jhunjhunu & 0.22 & 0.32 & -0.61 & 0.15 \\
\hline 9 & Jodhpur & 0.61 & -0.39 & -0.11 & -0.01 \\
\hline 10 & Nagaur & -0.12 & 0.10 & -0.14 & -0.08 \\
\hline 11 & Pali & -0.55 & 0.72 & -0.16 & -0.11 \\
\hline 12 & Sikar & 0.77 & 0.29 & 0.04 & 0.002 \\
\hline
\end{tabular}


On the basis of composite index (Table 3) four categories/zones have been worked out for each sector.

- Highly developed zone

- Medium developed zone

- Less developed zone

- Very less developed zone

These zones have been grouped and analysed under the four sectors - demographic, agricultural, economic and infrastructural sector and are discussed as under -

\section{DEMOGRAPHIC SECTOR}

This sector includes population growth (2001-2011), percentage of urban population to the total population and literacy rate according to census 2011. The districts of western Rajasthan have been grouped based on the level of development and shown in the map. The districts falling in highly demographic development zone are Bikaner, Jaisalmer, Jodhpur, and Sikar. They are developed in all demographic aspects, whereas Jaisalmer and Sikar are less developed in regard to urban population and Jodhpur has low literacy rate.

The districts like Barmer, Churu, Ganganagar, hanumangarh and Jhunjhunu comes in Medium developed zone. Here Churu, Ganganagar and Hanumangarh have less population growth but have good literacy rate while Barmer and Jhunjhunu has less percentage of urban population. The districts falling in less developed zone is Nagaur.

Lastly come the districts falling in very less developed zone, they are Jalore and Pali. These districts are very low in literacy rate.

\section{Agricultural Sector}

Agricultural sector constitutes give indices percentage in irrigated area to net cropped area, agricultural output per 1000 population, percentage of non-agricultural workers to total workers and percentage of double cropped area to total cultivated area. The level of agricultural development has been worked out and shown in map. Here Ganganagar and Hanumangarh districts fall in highly developed zone due to fertile plain. On the other hand Jhunjhunu and Sikar fall in medium developed zone.

The less developed zone, includes the districts like Churu, Jodhpur and Nagaur, where in these districts the percentage of irrigated area to net cropped area is less and has average condition in all the agricultural aspects except for percentage of non-agricultural workers which is quiet low. The districts falling in very less developed zone are Barmer, Jaiselmer, Jalore, Bikaner and Pali are those districts that have limitation of fertile soil due to large cover of sandy soil.

\section{ECONOMIC SECTOR}

Economic position of western Rajasthan was very dismal in the initial stage of planning. Only few districts of western Rajasthan show good position in economic profile while rest are even below average. The district Bikaner fall under highly developed zone. The districts falling in medium developed zone are Jaisalmer, Nagaur, Ganganagar, Hanumangarh and jodhpur. The districts like Ganganagar, Hanumangarh, Jodhpur and Nagaur show good percentage of main workers to the total workers while Jaisalmer show good number of livestock. The districts falling in less developed zone are Baran, Barmer, Churu, Jalore, Pali and Sikar. In these district population is involved more in agriculture and is having low literacy rate thus these are less developed in all economic aspects, also the district Jhunjhunu fall in very less economic developed zone.

\section{INFRASTRUCTURAL SECTOR}

This sector plays vital role in the level of development and act as the main instrument without which the study of regional disparities is incomplete. The indices have been selected for analysis namely road connectivity, electricity, educational centres, medical facilities, milk production and cooperative societies which indicates that may help in the identification of backward regions. The highly developed zone in this sector includes districts like Bikaner and Jhunjhunu. Thus these districts are well connected with other states through good transportation system, maximum educational and medical facilities and these districts have other high infrastructural facilities too. The district that fall in medium developed zone are Ganganagar, Hanumangarh, Sikar and Jodhpur. These districts show average conditions in infrastructural facilities. The less developed zone includes the districts like Chum, Jalore, Nagaur and Pali, while the very less developed zone includes Jaisalmer and Barmer. 


\section{Dr. Pawan Kumar Sharma}

All the above districts show less availability of infrastructure facilities and are sometimes nil in one or two indices with certain exceptions too. Due to the extremes of temperature, low fertility, less number or settlements connectivity and communication is less developed here.

\section{Spatial VARiation in Western Rajasthan}

On the basis of composite index, 12 districts of Western Rajasthan have been divided into 4 categories of level of development shown in the table. Higher value of composite index show higher level of development and vice versa.

Table4. Level of Development

\begin{tabular}{|l|l|l|l|}
\hline S. No. & Composite Index Value & Level of Development & Name of the district \\
\hline 1 & Above +0.30 & Relatively Developed & Ganganagar, Bikaner \\
\hline 2 & 0.0 to 0.30 & Less Developed & Jodhpur, Hanumangarh \\
\hline 3 & -0.30 to 0.0 & Least Developed & Churu, Jalore, Jhunjhunu, Sikar, Pali \\
\hline 4 & Less than -0.30 & Backward Regions & Nagaur, Jaisalmer, Barmer \\
\hline
\end{tabular}

\subsection{Relatively Developed}

The districts having composite index value more than 0.30 have been assigned with relatively developed zone. The districts falling in this category are Ganganagar and Bikaner. Ganganagar is at the top position with a composite index value of 0.75 in terms of level of development. The Ganganagar district has rich agricultural potential and in the stage of development due to the existence of Indira Gandhi Canal Project. The district has also average condition in urban population and non SC-ST population. Bikaner district has better condition in number of livestock and has average condition in transportation system and education.

\subsection{Lass Developed Zone}

This zone constitutes composite index value between 0 to +0.3 and the districts include in this category are Jodhpur and Hanumangarh. Hanumangarh has rich agricultural potential but have average conditions in totla urban population and literacy rate.

\subsection{Least Developed Zone}

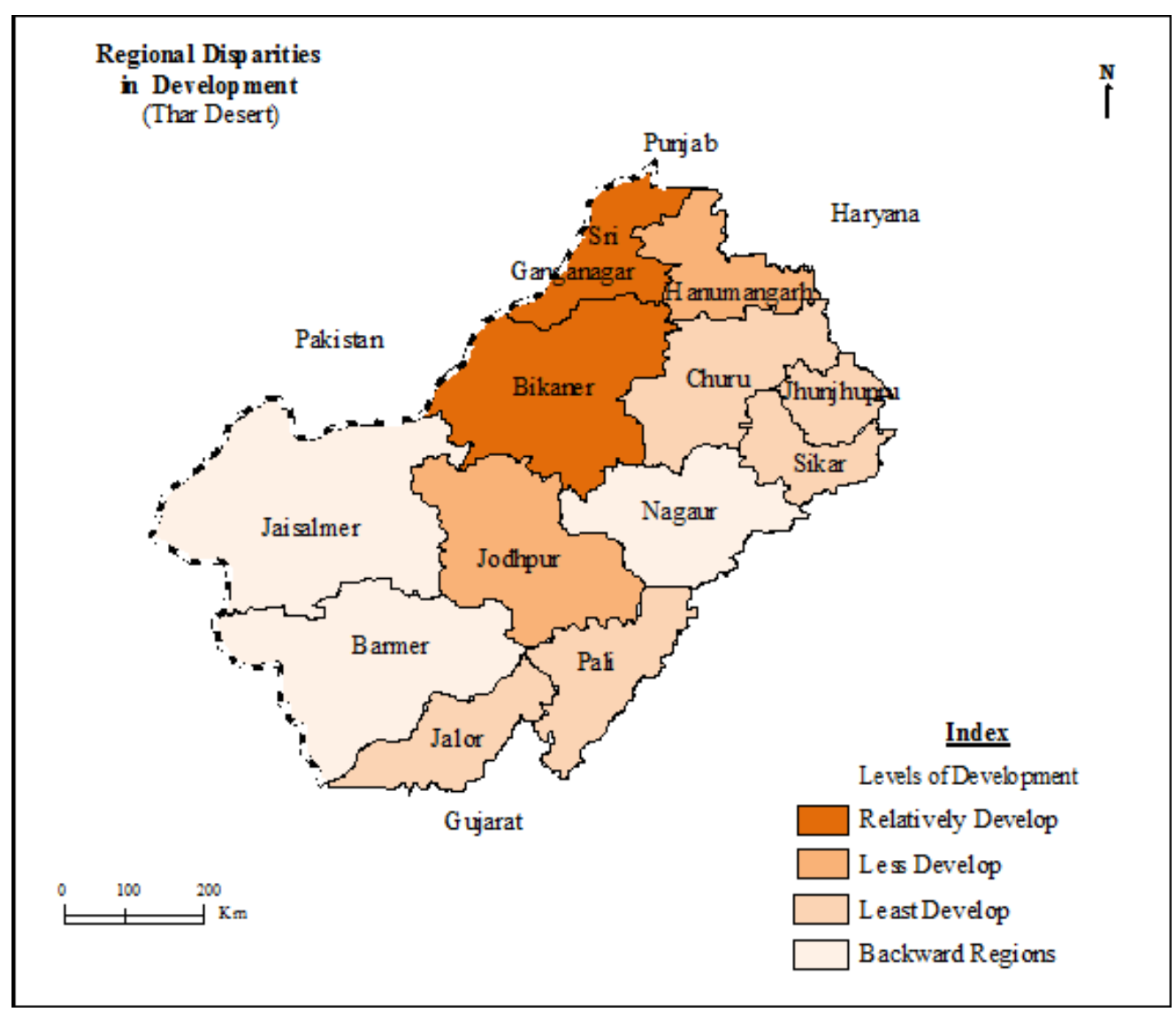

Fig2 
This zone includes 5 districts of western Rajasthan, they are Churu, Jalore, Jhunjhunu, Sikar and Pali with a composite index between -0.3 to 0.0 . Here Churu stands at good position in terms of sex ratio, literacy rate (both male \& female) but is less developed in terms of economic and infrastructural development.. Districts Jhunjhunu has good percentage of net cropped area and has second rank in literacy. Jalore stands at good position regarding the occupation and livestock but has the lowest female literacy rate and maximum percentage of rural population i.e. more than 90 percent. Sikar has also high literacy rate i.e. more than 70 percent of the total population but is less developed in terms of economic development, because of semi arid conditions.

\subsection{Backward Region}

The district having a composite index value less then -0.3 fall in the category of backward region and the district falling in the category are Nagaur, Jaisalmer and Barmer. District Jaisalmer and Barmer are situated in the Thar Desert where maximum land is under sand dunes and the area is lacking in infrastructural facilities like transportation, education and medical. Due to scattered settlement and more spacing among them it is difficult to provide infrastructure facilities at villages level because of lack of population and areal threshold. These districts are less developed in agriculture and percentage or urban population as well as literacy rate is also poor in these districts. Although having rich potential of mineral and power resources, these districts are unable to exploit these resources and utilize these to their maximum.

It may, therefore, be concluded from the above analysis that in western Rajasthan the general level of development is poor. Out of the total 12 districts, more than 65 percent numbering district fall under less developed or backward region. Only two districts are comparatively highly developed. This situation therefore demands process to be undertaken giving special attention and allocation of funds for development of lagging areas.

\section{Conclusion}

The main challenge of regional economic development is undoubtedly to increase the living standard and welfare of local people. Usually the state of development of regions and sub-regions within one country significantly differs. In Rajasthan, the eastern part is emerging, and the western part, mostly the ones by the boarder are lagging behind. Economic development should not be executed homogeneously, one should take into consideration the attributes and starting conditions of that certain area. The variety of starting conditions requires different interventions and strategies of economic development from region to region. Due to their different conditions they cannot be developed by the same action plans. This research helps to analysis dimensions of development and typology of backwardness and also useful to formulate a future Plan for the balanced regional development and a relevant strategy to minimize spatial variation in the level of development at micro-level.

\section{ACKNOWLEDGEMENT}

UGC for providing fund for the research under Start Up Project.

\section{REFERENCES}

[1] Bagchi, K. K. (2011) Regional Disparities in India's Socio-economic development, New Century Publications, New Delhi.

[2] Bharara, L.P.(1998): Man in Desert, CAZRI, Scientific Publication, Jodhpur, Rajasthan.

[3] Bhatt, L.S.(1972): Micro level Planning, K.B. Publication, New Delhi.

[4] Chand, M. and Puri, V.K.(2015): Regional planning in India, Allied publishers, New Delhi.

[5] Hotelling, H (1933): Analysis of a Complex of Statistical Variables in to Principal Components, Journal of Educational psychology, Vol. 24

[6] Jishi, Samir (1997). Regional Disparities in Industrial Development, Indian Journal of Regional Science, Vol. 29, No.1.

[7] Kundu A. and Raza.M. (1982). Indian Economy: The Regional Dimension, Spectrum, New Delhi.

[8] Mitra, A (1961): Levels of Regional Development in Census of India, Govt. Of India, New delhi, vol. 1 Part 1 
[9] Mishra R.N. \& Sharma P.K. (2003): Study of Rural Growth Centers for in Marusthali Region, Journal ANNALS, Vol.XXIII, NAGI. New Delhi

[10] Mishra R.N. \& Sharma P.K. (2007): Rural Growth Centers for Micro-level planning, Ritu Publication, Jaipur. Rajasthan.

[11] Mishra, R.P.(1978): Regional Development Planning in India, Vikash Publication, New Delhi.

[12] Mohan, K. (2005). Addressing Regional Backwardness: an Analysis of area Development Programmes in India, Manak Publication, New Delhi.

[13] Pal, M.N.(1975): Regional disparities in level of development in India, Vol.1 A-one Publishers , New Delhi.

[14] Raghuram Rajan Committee Report-2013, Raghuram Rajan Committee for Evolving a Composite Development Index of States Using Multi- Dimensional Index.

[15] Rao, Hemlata, (1984). Regional Disparities and Development in India, shish Publishing House, New Delhi.

[16] Shand, R and S. Bhide (2000). Sources of Economic Growth- Regional Dimensions of Reforms, Economic and Political Weekly, October 14, pp. 3747-3757.

[17] Shrivastava and Sharma (1997): Regional planning and Balanced development, Vasundhara Prakashan, Gorakhpur.

[18] Singh R. (2006). Regional Disparities in level of socio-economic Development in post Reforms Period: A District level Analysis, Annals of NAGI, Vol. 26, Dec., No.2, pp.8794.the International Trade.” Journal of Economic Geography

[19] Statistical Handbook, (2011) Directorate of Economic and Statistics, Govt of Rajasthan, Jaipur

[20] United Nations (1984). Population, Resource, Environment and Development, Oxford University Press, London, p.457.

\section{AUTHOR's BIOGRAPHY}

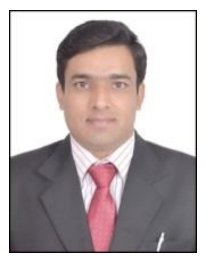

Dr. Pawan kumar Sharma, is position holder of University of Rajasthan in M.A., M.Phil.,(Geography) And Post P.G. Diploma in Population Ecology. He has been awarded by UGC- NET- JRF. Dr. Sharma has got his Ph.D. in Geography in 2005 from the University of Rajasthan. He is member of many national and international academic societies. He has a number of research papers on his credit. He is principal investigator of UGC Start -Up project on the Project title: Micro-level analysis of spatial variation in the level of development in western Rajasthan- A multi-dimensional approach. Presently he is working as Assistant Professor in Department of General \& Applied Geography, Dr. Harisingh Gour Central University, Sagar, M.P., India. 